\section{Iceland sharpens its harpoons}

\section{London}

A RESUMPTION of commercial whaling is in prospect after Iceland's chief delegate to the International Whaling Commission (IWC), Gudmunder Eriksson, said he will advise his government to leave the organization. Iceland's withdrawal from the IWC, which could take effect from 30 June 1992, would leave its whaling fleet free to hunt minke and fin whales in the central North Atlantic, irrespective of the wishes of the IWC.

The IWC imposed a ban on commercial whaling in 1986 when it was realised that the technique used by the commission to calculate catch quotas was seriously flawed: whale stocks could be depleted even by catches sanctioned by the IWC. Iceland grudgingly accepted this argument, but Norway and Japan, the other two main whaling nations, continued commercial hunting for another two seasons.

Iceland's strongest threat yet to leave the commission came in the closing minutes of an acrimonious IWC annual meeting, held in Reykjavik, Iceland, last week. Icelandic delegates were angered by what they saw as a deliberate attempt by the majority of anti-whaling nations within the IWC to delay the implementation of a "revised management procedure", devised by the IWC's scientific committee (see Nature 351, 259; 23 May 1991). This procedure (essentially a mathematical model based on whale population dynamics) should allow the setting of commercial catch quotas that do not endanger whale populations - at least for some stocks of the relatively numerous minkes. The IWC also refused to consider an Icelandic request to allow "interim" commercial catches of minke and fin whales over the coming year.

The IWC agreed to adopt the management procedure put forward by its scientists, even though this was seen as the first step towards the resumption of commercial whaling within the IWC, which most IWC members wish to prevent. But a resolution put forward by a hard-core group of nine anti-whaling nations - Australia, Finland, Germany, Oman, the Netherlands, the Seychelles, Switzerland, Britain and the United States - contains a number of caveats that will restrict the use of the procedure to set catch quotas.

The resolution, passed by 18 votes to six, also asks the IWC's scientific committee to do more work to refine the procedure. The Icelandic delegation believes that the antiwhaling nations will use uncertainty over the precise size of whale stocks, and the positions of the boundaries between them, as an excuse to delay the resumption of commercial whaling within the IWC.

The Icelandic cabinet must now weigh the advantages of resuming commercial whaling outside the IWC against the threat of econ-

omic sanctions from the United States. Under iㅗㄱeries legislation, the US Administration can ö impose sanctions on  whale populations.

Norway is also now reconsidering its membership of the IWC. Japan, while expressing disappointment about the IWC's decision, has made no immediate threat to leave. The Japanese hope that, if the revised management procedure is implemented next year, they will be given IWC quotas to catch minkes in Antarctica, where stocks are much larger than the North Atlantic populations that Iceland and

\title{
Greens in disarray after committing a tactical blunder
}

\section{London}

THE threatened fragmentation of the IWC. and with it the return of commercial whaling. is a major disappointment for the environ mentalist lobby, which had counted the IWC whaling ban among its successes.

But for environmentalist groups, the battle was lost not so much in last week's meeting of the full IWC, but rather during the two-week meeting of the IWC's scientific committee that preceded it. Once the IWC's scientists had chosen a single management procedure from the five they were considering, a clash between the anti-whaling IWC members and the whaling nations was inevitable (see Nature 351, 259; 1991).

The scientific committee, like its parent body, is a forum influenced by political hidden agendas, where scientists sympathetic to the environmentalist cause oppose those advising the governments of the whaling nations.
The anti-whaling members of the scientific committee had hoped the committee would be unable to choose between the five rival management procedures. Sidney Holt, scientific adviser to the Seychelles IWC delegation, says that all five procedures should have been put forward to the full IWC, with an explanation of each provided by the scientific committee. The choice of a single procedure "was a policy one, not a scientific one," he says.

But most committee members decided that the procedure developed by Justin Cooke, a British mathematician now working in Germany, was superior to the other four on offer - giving the best balance between protecting whale populations from depletion, maximizing catches and ensuring that catch quotas do not vary wildly from year to year.

Shocked by this development, a small group of anti-whaling scientists, ironically
Norway wish to hunt.

But that hope may be optimistic. Next year's IWC meeting is in Glasgow, Scotland, and British public opinion is set firmly against whaling. The British government is expected to oppose a resumption of whaling on humane grounds, irrespective of the conservation issue, arguing that no humane method of killing whales exists. Many other IWC nations are expected to support this stand.
Peter Aldhous including Cooke himself, objected to the selection of Cooke's procedure. If a single procedure was to be chosen, they said, it should be that developed by Bill de la Mare, an Australian who now works in the Netherlands. Among the five candidate management procedures, de la Mare's places the highest priority on the protection of whale stocks from depletion, and would delay the resumption of catches from heavily depleted populations for several decades. But the pleas of the antiwhaling scientists were to no avail, and Cooke's procedure was put forward to the full IWC.

The anti-whaling members of the scientific committee are seen to have committed a major tactical blunder, effectively being undermined by the mathematical talent of one of their own number. "They've shot themselves in both feet," said one informed observer in Reykjavik last week.

Peter Aldhous 